\title{
THE INFLUENCE OF CONCEPT ATTAINMENT MODEL IN MATHEMATICAL COMMUNICATION ABILITY AT THE UNIVERSITY STUDENTS
}

\author{
Lilis Marina Angraini* \\ Universitas Islam Riau
}

\begin{tabular}{l} 
Article Info \\
\hline Article history: \\
Received March 23, 2019 \\
Revised Sept 23, 2019 \\
Accepted Sept 25, 2019 \\
\hline
\end{tabular}

Keywords:

Concept Attainment Model, Mathematical Communication, Prior Mathematical Knowledge

\begin{abstract}
Based on data from observation and interview with lecturer who teaches mathematics course on the subject under study, it was found that students' mathematical communication ability is still low. This study aims the students' mathematical communication ability through Concept Attainment Model learning. The method in this study is two groups randomized subject post-test only. The number of subjects in this study were 82 students. The Kolmogorov-Smirnov test, Levene test, $t$ test, ANOVA one and two-way were used to analyse the data. The results of this study showed that (1) there is difference grade on the student's mathematical communication ability between experimental group and conventional group as a whole, (2) there is no difference on the students' mathematical communication ability of experimental classes based on their Prior mathematical knowledge (PMK); (3) there is no interaction between the learning that is used with the students' prior mathematical knowledge on the students' mathematical communication ability. The concept attainment model provides a better influence on students' mathematical communication ability, it is also necessary to see the influence of the concept attainment model on students' high-level mathematical thinking ability.
\end{abstract}

Copyright @ 2019 IKIP Siliwangi. All rights reserved.

\section{Corresponding Author:}

Lilis Marina Angraini,

Departement of Mathematics Education,

Universitas Islam Riau,

Jl. Simpang Tiga, Pekanbaru, Riau 28288, Indonesia.

Email: lilismarina@edu.uir.ac.id

\section{How to Cite:}

Angraini, L. M. (2019). The influence of concept attainment model in mathematical communication ability at the university students. Infinity, 8(2), 189-198.

\section{INTRODUCTION}

Committee of the Undergraduate Program on Mathematics (CUPM) provided six of basic recommendations for the department, programs, and also courses on mathematics (Barker et al., 2004). One of the recommendation stated that each course on mathematics should be an activity that will assist students on the development of analytical, critical reasoning, problem solving, and communication skills. The CUPM Recommendation that is explained, the task of institution in charge of the educating prospective teachers who will teach mathematics, including preparing students for having mathematical communication ability. Institutions of Higher Education Personnel (IHEP), Departement of Primary School 
Education which is on charge of childbirth prospective teachers who will teach mathematics partially take responsibility for preparing their students for having mathematical communication ability. Mathematical communication is the ability that could be cultivated, the lecturer has a role in the development efforts of students' mathematical communication ability.

Mathematical communication is an ability to communicate the mathematical knowledge properly and influenceively (Wood, 2012). Communication is the essential process in learning mathematics. Through communication, students are able for organizing, reflecting upon and clarifying ideas, relationships, mathematical thinking and the mathematical arguments. During mathematics learning, students communicate for various purposes (for presenting or justifying a solution, for expressing mathematical arguments or to put a question) and to different audiences (teacher, colleague, group of students, whole class) (Vale \& Barbosa, 2017).

Based on data from observation and interview with lecturer who teaches mathematics course on the subject under study, it was found that students' mathematical communication ability is still low. Mathematical communication ability is important for students to have, because by having good mathematical communication ability students will find it easier to communicate mathematical ideas they have. Concept attainment is a learning model that can bridge students 'mathematical communication ability, because in concept attainment learning there are steps that can train students in expressing mathematical ideas that they have, one of the steps that supports students' mathematical ability is the data presentation stage.

Bruner (Joyce \& Weil, 2011) said learning process will be going well and creatively, if lecturer give students the opportunity for finding a rule (including concepts, theories, definitions, and so on) through examples that describes/ represents rules that became a source, in other words, students are guided inductively for understanding a common truth.

Process of study was presented by Bruner is in line with theory of concept attainment model according by Joyce \& Weil (2011), concept attainment model is more focused on ways to strengthen the internal human impulses on understanding science, by digging and organizing, as well as developing language for expressing it. Bruner, Goodnow, and Austin reveal that concept attainment model deliberately designed for helping students to learn the concepts that can be used for organizing information, so it makes easy for students to learn concepts in more influenceive way (Anjum, 2014; Jones \& Hilaire, 2014).

Concept attainment model has several stages of learning, the stages in concept attainment models help to train students on mathematical communication ability. The first stage, namely the presentation of the data and the identification of the concept, in this stage, students are asked to compare the characteristic features on example and nonexample, students were asked to create and test the hypothesis, then the student making the definition of the concept on the essential characteristic features, here the students are trained to use critical thinking and also mathematical communication, because the students requested for comparing a characteristic features on examples and non-examples, and they find a definition of concept on characteristic of concept essential features (Bhargava, 2016; Jain \& Upadhyay, 2016).

The next stage is testing an achievement a concept, the students were requested for identifying examples a concepts and creating additional instances, the students are exercising for using critical thinking and mathematical communication, students who think the characteristics are represented in a concept and kind of example that fulfills a criteria of a concept (Kaur, 2014; Ostad \& Soleymanpour, 2014). 
The last stage is the analytical thinking, the students are requested for communicating mathematics, the students are asked for expressing a concept by their own words, explains the reasons relating for creating additional instances, and writing down a steps for resolving a task on concept being learned, and formulating a mathematical concept, and this is learning model proposed by Joyce \& Weil (2011) in theoretically sure that students' mathematical communication ability will more better (Kumar \& Mathur, 2013; Widiastuti, 2014).

Kauchak \& Eggen (2012) suggestion that concept attainment model is an inductive learning model, designed by lecturer for helping students to learn the concepts and trained the students in practicing high-level thinking skills. Concept attainment model is very relevant for teaching mathematics (Mondal, 2013), because this model can foster understanding and appreciation the students to understand the concepts, principles so grows the power of reason, think logically, critically, systematically and others.

Concept attainment model is a learning model that aims for helping students understanding a particular concept, it is more appropriate when the emphasize of learning is more focused in the introduction of a new concept, so as trained high-level thinking skills (Aningsih \& Asih, 2017; Sharma \& Pachauri, 2016).

The purposes of the study are: (1) To see the difference on students' mathematical communication who got the concept attainment model and students who got the conventional teaching; (2) To see the difference on students' mathematical communication who got the concept attainment model seen from the prior mathematical knowledge; (3) To see the interaction a learning and the prior mathematical knowledge on students' mathematical communication.

\section{METHOD}

The research was contained at one of Islamic State Universities. The population is all students in departement of Primary School Education 5th Semester. All population chosed as sample the control and experiment class. The number of subjects in this study were 82 students.The researcher chooses the fifth semester in departement of Primary School Education student, because mathematics courses in odd semester can be used as objects, to examine students' in-depth communication ability about mathematical concepts only in semester V, in addition, departement of Primary School Education students semester $\mathrm{V}$ are also a group of students who are deemed ready to accept the treatment of this research, with the aim of becoming their own experience in teaching mathematical concepts before they go into the field, to carry out teaching practices in schools. The population was chosen randomly from two classes as research samples, from these two classes then randomly selected one class that would be the experimental group, and one class that would be the control group with sampling techniques adapted to population conditions.

The test is two-dimentional figure that contains in a subject of Mathematics Education II. The instrument test mathematical communication composed three questions. An example of the problem. 
You are required to call a grade 2 elementary school students, who is not familiar with cartesian coordinates, but they are familiar with geometric shapes. You must explain the PQRS trapezoid image below (by telephone), so that the students can draw it exactly like the picture.

Write what you explained by telephone.

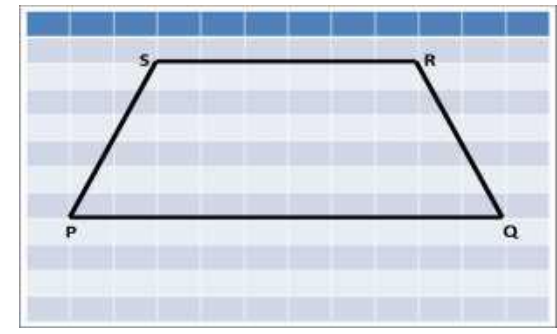

The data about mathematical communication ability of students is obtained through tests of mathematical communication ability. The Kolmogorov-Smirnov test, Levene test, $t$ test, ANOVA one and two-way were used to analyse the data. The t test was used to determine differences students' mathematical communication who got the concept attainment model and students who got the conventional teaching. The one-way ANOVA test was used to determine differences students' mathematical communication who got the concept attainment model seen from the prior mathematical knowledge. Two-way ANOVA test was used to determine the interaction a learning and the prior mathematical knowledge on students' mathematical communication. Before using the t test, the one-way and two-way ANOVA tests, the prerequisite tests are the normality of the data distribution test using the Kolmogorov-smirnov test and the homogeneity variance test of the data groups using the Levene test.

\section{RESULTS AND DISCUSSION}

\subsection{Results}

The data of prior mathematical knowledge is got and analysed for determining the students' prior mathematical knowledge before the research was worked. prior mathematical knowledge was got from grades a subject of mathematics education, it acquired in a fourth semester. The grade is clustered by 3 categories of high, medium and low. The results are prior mathematical knowledge data (Table 1).

Table 1. Data Equality Test of Prior Mathematical Knowledge

\begin{tabular}{ccc}
\hline T-Test & Data & Criteria \\
\hline $\mathrm{N}$ & 82 & $\mathrm{H}_{0}$ Accepted \\
Sig. (2-tailed) & 0.23 & \\
\hline
\end{tabular}

Table 1 explains there is no difference of prior mathematical knowledge between students who got concept attainment model and students who got conventional model. The data equivalence of students' mathematical communication based on models shows in the Table 2.

Table 2. Equality of Matematical Communication

\begin{tabular}{ccc}
\hline T-Test & Data & Criteria \\
\hline N & 82 & $\mathrm{H}_{0}$ Rejected \\
Sig & 0.00 & \\
\hline
\end{tabular}


Table 2 explains there is difference between students' mathematical communication who got concept attainment model and students who got conventional model. A results of students' mathematical communication who got concept attainment model shows in the Table 3.

Table 3. Test of One-Way ANOVA

\begin{tabular}{cccccc}
\hline & $\begin{array}{c}\text { The sum of } \\
\text { Squares }\end{array}$ & Df & Average & F & Sig. \\
\hline Inter-group & 666.97 & 2 & 333.48 & 2.44 & 0.10 \\
In a group & 5602.66 & 41 & 136.65 & & \\
Total & 6269.63 & 43 & & & \\
\hline
\end{tabular}

Table 3 explains there is no difference students' mathematical communication who got concept attainment model based on prior mathematical knowledge. Furthermore, a results of an influence of interaction between learning model and prior mathematical knowledge shows in the Table 4.

Table 4. Test of Two-Way ANOVA

\begin{tabular}{lccccccc}
\hline & $\begin{array}{c}\text { The sum } \\
\text { of Squares }\end{array}$ & Df & Average & F & Sig. & $\mathbf{H}_{\mathbf{0}}$ \\
\hline Learning & 3242.61 & 1 & 3242.61 & 26.95 & 0.00 & Rejected \\
Prior Mathemetical Knowledge & 1727.85 & 2 & 863.92 & 7.18 & 0.00 & Rejected \\
Interaction & 72.03 & 2 & 36.01 & 0.29 & 0.74 & Accepted \\
Error & 9142.45 & 76 & 120.29 & & & \\
Total & 132264.00 & 82 & & & & \\
\hline
\end{tabular}

Table 4 explains a learning factor that used in each group has impact on students' mathematical communication. Prior mathematical knowledge factor had significant impact on students' mathematical communication. There is no influence caused by an interaction between learning model and prior mathematical knowledge on the students' mathematical communication.

\subsection{Discussion}

Based on overall there is difference in mathematical communication ability of students who are taught with the concept attainment model with students who are taught with conventional learning. From the previous data it can be seen that the mathematical communication ability of students who get the concept attainment learning model is better than students who get conventional learning. 
There is a better improvement in the mathematical communication ability of students who are taught with the concept attainment model, than students who are taught with conventional learning, theoretically due to the concept attainment model, there are steps that can facilitate an increase in students' mathematical communication ability, These steps are: The first learning stage (Joyce \& Weil, 2011), namely the presentation of data and identification of concepts, at this stage students are asked to compare the characteristics in the examples and non examples, students are asked to make and test hypotheses, then students make definitions of concepts for essential features, here students are trained to communicate because students express their ideas about the essential features of the concept.

The second stage of learning (Joyce \& Weil, 2011), namely the stages of testing the achievement of concepts, at this stage students are asked to identify examples of concepts and make additional examples, here students are re-trained to communicate their ideas about what characteristics represent a concept and examples of what meets the criteria of the concept. In the third learning phase (Joyce \& Weil, 2011), students are asked to express concepts in their own words, express reasons related to making additional examples, and write steps for problem solving of the concepts being studied, as well as formulate the mathematical concept.

During the learning process there are several things that concern the researcher regarding the mathematical communication skills of students at each stage of learning using CAM. At the data presentation stage, the student as a whole looks carefully at it. The data presentation stage is the introduction stage of the general description of the concepts learned and an explanation of the work steps of the concept in the problem solving process. The role of students in this stage is to examine it, capture the intent and meaning, analyze the characteristics possessed by the concept.

At the stage of testing the concept achievement, student activities take place by discussing with friends beside him. Students are asked to discuss to identify the characteristics of the concepts learned then find concepts based on the characteristics they have found. The role of the lecturer here provides stimuli so that they are able to find concepts through their own discoveries.

Furthermore, at the stage of thinking strategy analysis, students are asked to reveal the reasons relating for formulating the concept by their own words and writing the concept through writing. The following will be presented the answers to the results of the discussion they did on the high line material, dividing lines, and the weight lines on the triangle.

\section{1. garis tinggi adalah garis tegak lurus yang membentuk- sudut siku-siku.}

2. Garis bagi adalah garis yang membentuk sudut yang sama.

3. garis berat adalah garis yang membagi dua sisi yang sama pantahy.

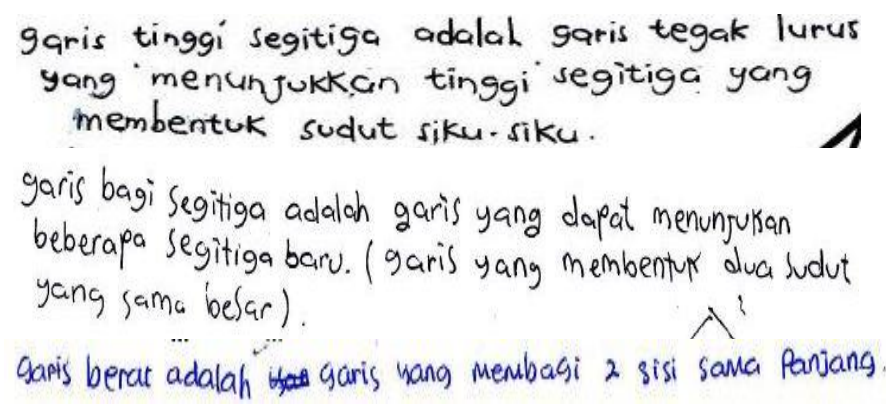

Figure 1. Answers of Experimental Class Discussions

Figure 1 shows the answers of students when conducting discussions during learning. Group 1's answer states that the high line is a perpendicular line forming a right angle. Bisector is a line that forms the same angle. A weight line is a line that divides two 
sides of equal length. While the other group states that the height of the triangle is the perpendicular line showing the height of the triangle forming a right angle. Bisector is a line that can show several new triangles (a line that forms two equal angles). A weight line is a line that divides two sides of equal length.

The results above illustrate that the thinking process they are doing is right and there is something that is not right. After the discussion process took place, the lecturer gave confirmation about the accuracy of the concepts learned, so that students who were not right in the process of finding the concept got directions about the mistakes they did.

Based on the results of tests on students' mathematical communication skills tests, several errors were found by students who received learning concept attainment models, namely errors in algebraic completion, for example: $5 \mathrm{a}+105=0$, then $5 \mathrm{a}=105$, then $\mathrm{a}=$ 21. Then there are students who solve questions like the following $13+13+\sqrt{50}+\sqrt{50}=$ $13+13+10=36$. Although during learning, lecturers always straighten out the mistakes made by students in algebraic operations, but when the variables change, these errors still occur. This is evident when students complete questions about mathematical communication skills in the final test.

Learning by using concept attainment models (CAM) provides a fairly good influence on the mathematical communication skills of students, this is evident from the acquisition of the average overall mathematical communication skills obtained by the experimental class is 6.9. This average is taken from the results of normalizing the data on the mathematical communication skills of students. Although the average mathematical communication ability of the control class is higher, which is 8.5 , this does not mean that the learning of the CAM model is not better than conventional learning. The average communication ability of the experimental class is lower than the control class caused by various factors.

The first factor is there are still many students in the experimental group who did not yet know ta basic concepts of algebraic, during a learning the researcher is more concern on correcting concepts, consequently learning in concept attainment model is less impact because the student's unbalanced abilities. Concept attainment model emphasizes finding a concepts by their own selves. A students are still incorrect on their mathematical concepts, the learning is increasingly constrained, lecturer must correct concept that are incorrect, then can only continue a learning material.

The second factor is the big number on students in one group (experimental group), which is 44 students, the researcher is somewhat inundate on providing impulse and they will reach a concept. From 44 students, only 15 students have a good point basic concept. During a learning lecturers came to students (whose basic mathematical concept were not well enough) step by step to provide impulse about teaching material so that students still get their own concepts.

The third factor, the number of students who are late in class, so the influenceiveness of learning time is not optimal, it should be 2.5 hours of learning time but because many students are late the average learning only runs for 2 hours each time meeting. Lecturers are constrained by students who arrive late, because they cannot balance the material with their friends. Especially if there are students who are not present at the previous meeting, this makes the lecturer have to explain to the student about the previous material. 


\section{CONCLUSION}

The conclusions of the problems in this researchs are: (1) There is difference on students' mathematical communication who got the concept attainment model and students who got the conventional teaching; (2) There is no difference on students' mathematical communication who got the concept attainment model seen from the prior mathematical knowledge; (3) There is no the interaction a learning and the prior mathematical knowledge on students' mathematical communication. The concept attainment model provides a better influence on students' mathematical communication ability, it is also necessary to see the influence of the concept attainment model on students' high-level mathematical thinking ability.

\section{REFERENCES}

Aningsih, A., \& Asih, T. S. N. (2017). Analisis Kemampuan Pemahaman Konsep Matematika Ditinjau dari Rasa Ingin Tahu Siswa pada Model Concept Attainment. Unnes Journal of Mathematics Education Research, 6(2), 217-224.

Anjum, S. K. (2014). A Study of effect of concept attainment model on achievement of geometric concepts of VIII standard students of english medium students of Aurangabad City. Scholarly Research Journal for Interdisipliner Studies, 2(15), 2451-2456.

Barker, W., Bressoud, D., Epp, S., Ganter, S., Haver, B., \& Pollatsek, H. (2004). Undergraduate Programs and Courses in the Mathematical Sciences: CUPM Curriculum Guide, 2004. Mathematical Association of America. 1529 Eighteenth Street NW, Washington, DC 20036-1358.

Bhargava, R. (2016). Effect of concept attainment model on achievement in social sciences. International Journal of Science and Research. 5(5), 699-701.

Jain, V., \& Upadhyay, H. (2016). Influence of Concept Attainment Model and Concept Attainment Integrated with Cooperative Learning on Teaching Sanskrit of Class VIII Students. The International Journal of Indian Psychology, 3(2).

Jones, J. L., \& St Hilaire, R. (2014). Concept Learning in the Undergraduate Classroom: A Case Study in Religious Studies. International Journal of Instruction, 7(2), 65-74.

Joyce, B., \& Weil, M. (2011). Models of Teaching. Yokyakarta: Pustaka Pelajar.

Kauchak \& Eggen. (2012). Strategies and Models for Teachers: Strategi dan Model Pembelajaran. Penerjemah : Satrio Wahono. Jakarta : PT Indeks.

Kaur, N. (2014). Effect of Concept Attainment Model of Teaching on Achievement in Physics at Secondary Stage. International Journal of Advance Research in Education Technology and Management, 1(1), 34-42.

Kumar, A., \& Mathur, M. (2013). Effect of concept attainment model on acquisition of physics Concepts. Universal Journal of Educational Research, 1(3), 165-169.

Mondal, B. C. (2013). Teaching science through information processing model: A review. Journal of education and practice, 4(9).

Ostad, G., \& Soleymanpour, J. (2014). The Impact of Concept Attainment Teaching Model and Mastery Teaching Method on Female High School Students' Academic 
Achievement and Metacognitive Skills. International Journal of Innovative Research in Science, Engineering and Technology, 3(2), 9774-9781.

Sharma, A., \& Pachauri, D. (2016). Comparison of advance organizer and concept attainment model for teaching concepts of science to standard IX. International Journal of Educational Research and Technology, 7(1).

Vale, I., \& Barbosa, A. (2017). The importance of seeing in mathematics communication. Journal of the European Teacher Education Network, 12, 49-63.

Widiastuti. (2014). Penerapan Model Pembelajaran Pencapaian Konsep Untuk Meningkatkan Hasil Belajar Siswa Kelas VII Pada Materi Himpunan Di MTs Nurul Hasanah Pengawu. Jurnal Elektronik Pendidikan Matematika Tadulako. 2(1).

Wood, L. N. (2012). Practice and conceptions: Communicating mathematics in the workplace. Educational Studies In Mathematics, 79(1), 109-125. 
